\title{
RESPOSTA FITOTÉCNICA DO ALGODOEIRO HERBÁCEO BRS 8H, BRS ARARIPE E BRS AROEIRA SOB LÂMINAS DE ÁGUA.
}

José Rodrigues Pereira ${ }^{1}$, Whéllyson Pereira Araújo ${ }^{2}$, José R. Cortez Bezerra ${ }^{1}$, João Henrique Zonta ${ }^{1}$, Hugo O. Carvalho Guerra ${ }^{2}$, Érica S. A. Barbosa de Almeida ${ }^{3}$, Francisco P. Cordão Sobrinho ${ }^{4}$, Ramon Araújo de Vasconcelos ${ }^{1}$

${ }^{1}$ Embrapa Algodão (jose.r.pereira@embrapa.br), ${ }^{2}$ UFCG, ${ }^{3}$ UFPB, ${ }^{4}$ Coteminas

O uso da irrigação tem contribuído para aumento da produção agrícola e para incorporação ao sistema produtivo de áreas cujo potencial é limitado, em função de seus regimes pluviométricos. Visando racionalizar os recursos hídricos e obter um maior retorno econômico, é importante que se identifique as necessidades hídricas das novas cultivares de algodoeiro herbáceo, de modo a aperfeiçoar o processo produtivo e preservar o meio ambiente. Então o objetivo do trabalho foi avaliar o crescimento e o rendimento de três cultivares de algodoeiro herbáceo em diferentes lâminas de água. Um experimento foi conduzido no Campo Experimental da Embrapa Algodão no Município de Barbalha-CE, no período de agosto de 2011 a janeiro de 2012. Os tratamentos consistiram da combinação fatorial $(3 \times 5)$ de três cultivares de algodão (BRS 8H, BRS Araripe e BRS Aroeira) e de cinco lâminas de irrigação ( $L 1, L 2, L 3, L 4$ e L5) equivalentes a uma lâmina total aplicada de 283,$11 ; 335,61 ; 423,48$ e $641,98 \mathrm{~mm}$, respectivamente. Utilizou-se delineamento em blocos casualizados, dispostos em faixas, com quinze tratamentos e quatro repetições, totalizando sessenta subparcelas. A quantidade de reposição de água $(\mathrm{mm})$ para cada tratamento e evento de irrigação foi determinada de acordo com a evapotranspiração de referência (ETO) calculada pelo método de Penman-Monteith. Na colheita, foram medidos, em 10 plantas/subparcela, o diâmetro do caule, a altura de planta, a área foliar e o rendimento das cultivares de algodoeiro herbáceo estudadas. Os resultados foram submetidos à análise de variância (Teste F) e as médias comparadas pelo teste de Tukey a $5 \%$ de probabilidade para o fator qualitativo (Cultivares) e à análise de regressão para o fator quantitativo (Lâminas de água), utilizando-se o programa estatístico SISVAR. O diâmetro do caule e a altura das plantas foram influenciados pelas lâminas de irrigação, mas a área foliar, não. Ambas as variáveis aumentaram linearmente com o conteúdo de água do solo, atingindo valores máximos de $12,52 \mathrm{~mm}$ e $91,71 \mathrm{~cm}$ na lâmina máxima de água aplicada, com acréscimo de 25,45 e 28,34\% comparando-se as lâminas de água mínima $(283,11 \mathrm{~mm})$ e máxima (641,98 mm) aplicadas. Para a variável rendimento a cultivar BRS 8H obteve comportamento crescente na medida em que aumentou a lâmina de água aplicada, com rendimento máximo calculado de 4953,65 $\mathrm{kg} \mathrm{ha}^{-1}$ alcançado na lâmina de 577,06 mm, decaindo a partir desse ponto. Para as cultivares BRS Araripe e BRS Aroeira os rendimentos foram crescentes com o aumento da lâmina de irrigação, com rendimento máximo na lâmina máxima de água (641,98 mm) de 5178,74 e $5254,25 \mathrm{~kg} \mathrm{ha}^{-1}$ respectivamente, com acréscimos em seus rendimentos entre as lâminas mínima $(283,11 \mathrm{~mm})$ e máxima $(641,98 \mathrm{~mm})$ de água de 25,78 e $23,71 \%$, respectivamente. Concluiu-se que o diâmetro do caule e a altura de planta foram influenciados somente pelas lâminas de água aplicadas, enquanto que o rendimento foi influenciado pelas cultivares e pelas lâminas de água. Destacando-se a cultivar BRS Aroeira, seguida da BRS Araripe e da BRS $8 \mathrm{H}$. 